\title{
The Meaning of Functions in the Beretes Traditional Ceremony of the Lombok Sasak Tribe (A Roland Barthes's Semiotics Study)
}

\author{
Abdullah*, I Ketut Sunarya ** \\ Faculty of Languages and Arts, Yogyakarta State University, Yogyakarta, Indonesia \\ ${ }^{*}$ Corresponding author, Email: Abdulldull4@gmail.com \\ ${ }^{* *}$ Corresponding author, Email: ketut_sunarya@uny.ac.id
}

\begin{abstract}
The cultural diversity inherited from ancestors has certainly become an invaluable resource for this nation. One of the cultural resources passed down from ancestors is traditional ceremonies. The Beretes traditional ceremony of the Lombok Sasak Tribe is one of the ceremonies that is still held by some parts of society. This study aims to describe the meaning of the Beretes traditional ceremony functions of the Lombok Sasak tribe. This is a qualitative research using a semiotic approach. Observations and interviews were conducted to obtain data on Beretes traditional ceremony. Data analysis employed data reduction, data presentation, and drawing conclusions or verification. The findings reveal that there is meaning in the Beretes traditional ceremony functions of the Lombok Sasak tribe as it contains social and moral values, while also serves as a social control on the society to prevent disgraceful deeds.
\end{abstract}

Keywords: Beretes traditional ceremony, Lombok Sasak tribe, Roland Barthes'semiotics

\section{INTRODUCTION}

Humans are the core of culture itself. Culture refers to the entirety of human development process. Culture is the full manifestation of the products of human thoughts, will, and feelings in the context of personal development in relation to the self, humankind, nature, and God [1]. Culture can also be defined as the entire system of human ideas, actions, and works in social life that is adopted by the individual through learning [2]. Essentially, culture can be described as values that emerge from the interaction process of individuals, that is admitted whether directly or indirectly, along the time within the interaction. The values even occur in the individual's subconscious and are passed down to the next generation [3]. The nation of Indonesia has incredibly rich cultural heritages which become their national pride.

Traditional ceremonies are one of the cultural heritages of the Indonesian people. The diversity of ethnic groups in Indonesia is represented by the distinct and unique character of each region, especially in the traditional rites. Traditional ceremonies are one of the customs that are passed down by ancestors and believed to be full of spiritual and religious values, in addition to having their own meaning. Traditional ceremonies are related to various functions which make them greatly central to the life of the society.

The Sasak tribe is a traditional group of community that has inherited the culture of traditional ceremonies. The people of Sasak in Lombok still hold and practice the traditions and customs of their ancestors, which makes their life full of rituals. The people of Sasak believe in the values of traditional ceremonies and hold them as a form of respect and to preserve the culture of the ancestors. One of the traditional rites that they still hold today is the Beretes birth ceremony, as well as molangmaliq, ngurisan, and nyunatang. Beretes or bisok tian is held to celebrate seven-month of pregnancy and contains meanings which reflect the social and moral values.

Today, along with the arrival of the digital era, the Beretes traditional ceremony begins to be marginalized and abandoned, as only a few parts of the society remain preserving the tradition. In order to further prevent this, there needs to be a theoretical and empirical study to offer an understanding for the society to preserve and reintroduce this tradition that has been passed down from the previous generations. 


\section{LITERATURE REVIEW}

\subsection{Beretes Traditional Ceremony}

The Beretes rite is a part of the traditional birth ceremony of the Sasak tribe. The ceremony represents the human life cycle and includes Beretes/Retesembet rite for the seven-month pregnancy [4]. This study attempts to offer an insight on the meaning of the Beretes ceremony's functions.

\subsection{Semiotics}

Semiotics is a science or analytical method for studying signs. Signs are devices that are used in an effort to look for meaning in the world, among people, and along with people. According to Barthes, semiotics essentially aims to study how to find meaning in a reality. Finding meaning in this case shall not be confused with communicating, as the former refers to how the existing objects not only bring information, but also constitute a structured system of signs [5].

Additionally, semiotics refers to a branch of discipline which deals with the study of signs and everything related to signs, such as signs and processes that apply to the sign users. Signs are a crucial element in behavior and communication as they may generate various meanings to make the message received and understood [6].

\subsection{Roland Barthes's Semiotics}

This theory was put forward by Roland Barthes around 1915-1980. As a scholar who studies and follows Saussure, he puts the emphasis on the interaction between the text and the personal and cultural experiences of the user, as well as the interaction between the convention in the text that is experienced and expected by the user. In his semiotic theory, Barthes develop a systematic model in analyzing the meaning of a sign, which is known as the order of signification. It includes denotation as the firststage signification (the actual meaning of a sign) and connotation as the second-stage signification (the double meanings of a sign resulted from cultural and personal experiences). There lies the difference between Saussure and Barthes' theories, although Barthes remains using Saussure's terms of the signifier and the signified.

a) Denotation: Denotation is the first-stage signification which explains the relation between the signifier and the signified of a sign, as well as between the sign and the object it represents in the external reality. In other words, denotation refers most actual meaning of a sign. b) Connotation: Connotation is the secondstage signification which explains the relation between the signifier and signified with nonexplicit, indirect, and uncertain meaning. Such meaning may be formed as the signifier is related with various psychological aspects such as feelings, emotions, or faith.

c) Myth: In the semiotic theory by Barthes, myth may be explained through the three elements of signage, namely the sign, signifier, and signified [7]. This study uses Barthes's semiotic analysis to examine the meaning of Beretes traditional ceremony.

\section{RESEARCH METHODOLOGY}

This is a qualitative study with a semiotic approach. Observations and interviews were done to obtain data on Beretes traditional ceremony. In a qualitative research, data is presented with words instead of numbers. The data are obtained from observations, interviews, and document analysis [8]. In this study, data were obtained using the three techniques, namely through documents related on the topic, and interviews with informants who were prominent community figures in the Sasak tribe to ensure the validity of data. Next, data were analyzed based on Barthes's semiotics. The data analysis involved data reduction, data presentation, and drawing conclusions or verification.

\section{RESULTS AND DISCUSSION}

\subsection{Beretes Traditional Ceremony}

With the advancement of the digital era, the Beretes rite merely seems as a reminder or a medium to express gratitude and joy for the blessing of God Almighty that is the seven-month pregnancy. It is in fact a part of a series of ceremonies of the Lombok Sasak tribe involving beretes, molangmaliq, ngurisan, and nyunatang. From the four ceremonies in the series of birth rites of the Sasak tribe, Beretes is special as it is held before the child is born, namely during the sevenmonth pregnancy, while the other ceremonies are conducted once the child is born. The Beretes ceremony naturally consists of a set of rituals in its procession.

The ceremony begins with tahlilan and dzikir by reciting the Qur'an as an expression of joy and prayer or hope for God's blessing. This is due to the fact that most of the Sasak community are Muslims. Next, the procession begins by showering the mother-to-be with flower water and wiping the pregnant belly with the flower water, as well. The hair is then washed using coconut milk. During the procession, jamjaman (a folksong in the native language containing prayer for the mother-to-be and the unborn child) continuously 
accompanies the whole rite process. In the ritual, the Beretes ceremony is led by a belian (shaman).

In an interview with Mamiq Lalu Abdurrahim, a prominent figure among the Sasak community, it is revealed that the Beretes ceremony has several functions, as follows:

a) to serve as an expression of gratitude for the blessing of God Almighty and the health in the pregnancy;

b) to share the news with the community about a new member in the family that is soon to be born; and

c) to show the financial status of the family.

\subsection{Roland Barthes's Semiotic Analysis on the Functions of Beretes Traditional Ceremony}

As previously explained, traditional ceremonies have functions and values, hence they are close to the daily life of the community. The Beretes traditional ceremony is no exception, as it has several functions, as well. In regard to this, this study focuses on the analysis on the meaning of the Beretes ceremony's functions.

a) Function I

1) Denotation: As an expression of gratitude for the blessing from God Almighty and for the health in the pregnancy.

2) Connotation: As pregnancy enters the seven-month milestone, mother-to-be may not only experience joy, but also worry. Nearing the labor, especially for first-time pregnancy, the Beretes ceremony may help prepare the mental state of pregnant women.

b) Function II

1) Denotation: As a medium to share the news with the community about a new member in the family that is soon to be born.

2) Connotation: Sharing the happy news with the community means sharing the responsibility to teach and become role models for the child to help one another as a future member of the society, especially in the development of the child's social life.

\section{c) Function III}

1) Denotation: To show the financial status of the family.
2) Connotation: There is a message that there is no need to go overboard or excessive in life, and that each person has their own limit.

Essentially, the functions of the Beretes traditional ceremony are the denotations in the perspective of Roland Barthes's semiotics, while the connotation refers to the social control among the society, especially for teenagers to be individuals with strong morals and good characters, so that they will not fall into disgrace by committing zinah (premarital sex) which can result in unwanted pregnancy.

\subsection{Myths in the Functions of Beretes Traditional Ceremony}

The myths surrounding the Beretes traditional ceremony emerges and develops naturally, in which the denotative and connotative meanings of the functions of Beretes ceremony seem to serve merely as symbols. The following are a few examples of the myths surrounding the Beretes ceremony:

a) The pregnant woman will return to the state of purity after being bathed with the flower water.

b) Wiping the pregnant belly with the flower water can make the labor process go well and easier.

c) The child will have a good character and good looks.

It is observed that the myths surrounding the Beretes traditional ceremony are based on the ritual procession in the ceremony itself.

\section{CONCLUSION}

The meaning of functions in the Sasak tribe's Beretes traditional ceremony certainly cannot be separated from the social and moral values reflected in the points, i.e.

a) helping to prepare the mental state of the mother-to-be in facing labor;

b) the community taking part in the responsibility of teaching social life for the child;

c) recognizing the limitations of each individual; and

d) serving as a social control for the members of community, especially the teenagers, to become individuals with good morals and characters to avoid disgraceful deeds, such as zinah. 
The myths that emerge naturally are strengthened based on the ritual procession, namely:

a) women returning to the state of purity after being showered with the flower water;

b) wiping the pregnant belly with flour water will make the labor process easier; and

c) the baby will turn out to have a good character and good looks.

\section{REFERENCES}

[1] Moertopo, A. Strategi Kebudayaan [Cultural Strategies]. Yayasan Proklamasi, Centre for Strategic and International Studies, 1978.

[2] Wina, P., \& Habsari, N. T. Peran Perempuan Dayak Kanayatn Dalam Tradisi Upacara Naik Dango (Studi Di Desa Padang Pio Kecamatan Banyuke Hulu Kabupaten Landak Kalimantan Barat) [The Role of Kanayatn Dayak Women in the Tradition of Rising Dango Ceremony (Study in Padang Pio Village, Banyuke Hulu District, Landak Regency, West Kalimantan)]. Agastya: Jurnal Sejarah dan Pembelajarannya, vol. 7, no. 1, 2017, pp. 104-126. DOI: 10.25273/ajsp.v7i01.1063

[3] Sabila, A. Nyelabar dalam perkawinan adat sasak di Desa Saribaye Kec. Lingsar (Seni Bernegosiasi Masyarakat Suku Sasak) [Nyelabar in a traditional sasak marriage in Saribaye Village, Kec. Lingsar (The Art of Negotiating in the Sasak Tribe Society)]. Doctoral dissertation. Universitas Islam Negeri Mataram, 2017.

[4] Suhupawati, S. Upacara Adat Kelahiran Sebagai Nilai Sosial Budaya Pada Masyarakat Suku Sasak Desa Pengadangan [Traditional Birth Ceremony as a Socio-Cultural Value in the Sasak Tribe of the Pengadang Village]. Historis: Jurnal Kajian, Penelitian dan Pengembangan Pendidikan Sejarah, vol.2, no.2, 2017, pp. 15-23. DOI: 10.31764/historis.v2i2.188

[5] Sobur, A. Semiotika Komunikasi (cetakan keempat) [Communication Semiotics (4th edition]. PT Remaja Rosdakarya, 2009.

[6] Zoest, A. V. Semiotika: tentang tanda, cara kerjanya dan apa yang kita lakukan dengannya [Semiotics: about signs, how they work and what we do with them]. Yayasan Sumber Agung, 1993.

[7] Adilia, W. F., \& Said, I. M. Ritual Posuo 'Pingitan' pada Masyarakat Suku Buton: Kajian Semiotika [The Posuo Ritual of 'Pingitan' in Buton Tribal Communities: A Semiotic
Study]. Jurnal Ilmu Budaya, vol. 7, no. 2, 2019, pp. 273-281. DOI: 10.34050/jib.v7i2.7952

[8] Rohidi, T. R. Metodologi Penelitian Seni [Art Research Methodologies]. CV Cipta Prima Nusantara, 2011. 